\title{
Teoretyczne i aplikacyjne aspekty konkurencyjności - przegląd literatury
}

\section{Wstęp}

Konkurencyjność, choć jest jedną z podstawowych kategorii stosowanych w naukach ekonomicznych, nie jest ściśle wyjaśnionym pojęciem. Przyjmuje się, że wyłoniło się ono w 1970 roku, kiedy amerykańscy ekonomiści, w obliczu zaostrzonej walki o handel między przedsiębiorstwami amerykańskimi i japońskimi, podjęli pierwsze próby określania stopnia konkurencyjności rywalizujących ze sobą gospodarek [Wziątek-Kubiak 2003]. Według innych źródeł, zainteresowanie tą kategorią ekonomiczną zapoczątkowane zostało wraz z kryzysem naftowym na świecie i związaną z nim utratą przewag komparatywnych w niektórych gałęziach przemysłu przez kraje wysoko rozwinięte [Lech 2001]. Mimo iż konkurencyjność przyciąga uwagę od prawie półwiecza, dopiero w ostatnich latach uwidacznia się dynamiczny rozkwit związanych z nią badań poprzez częste sprowadzanie oceny wielu zjawisk i procesów gospodarczych do miana konkurencyjnych bądź też niekonkurencyjnych. Problematykę konkurencyjności analizuje się zarówno w skali makro-, mezo-, jak i mikroekonomicznej. Barierą badań są jednak problemy związane ze ścisłym zdefiniowaniem oraz pomiarem konkurencyjności oraz zmiennością jej determinant w czasie i przestrzeni. To właśnie te kwestie były powodem podjęcia niniejszej pracy.

\section{Cel, zakres i metody badań}

Głównym celem pracy jest przegląd definicji, mierników i determinant konkurencyjności oraz koncepcji i teorii ekonomicznych z nią związanych. Dodatkowym celem pracy jest ukazanie problematyki konkurencyjności z punktu widzenia wybranych badań empirycznych na świecie. 
Przedstawiając w pracy koncepcje i teorie ekonomiczne konkurencyjności przeanalizowano ważniejsze nurty i szkoły ekonomiczne. Problematykę konkurencyjności ukazano w skali makro-, mezo- i mikroekonomicznej. Z metod badawczych zastosowano jedynie studium literatury przedmiotu. Wszystkie wyniki badań przedstawiono $\mathrm{w}$ ujęciu tabelarycznym $\mathrm{i}$ graficznym.

\section{Definicje konkurencyjności}

$\mathrm{Z}$ dokonanego przeglądu literatury wynika, że konkurencyjność ma bardzo wiele definicji, dlatego w pracy ukazano tylko wybrane $\mathrm{z}$ nich (tab. 1).

\section{Tabela 1}

Definicje konkurencyjności według wybranych autorów

\begin{tabular}{|l|l|}
\hline Autor [rok] & \multicolumn{1}{|c|}{ Definicja } \\
\hline $\begin{array}{l}\text { Adamkiewicz- } \\
\text {-Drwiłło [2002] }\end{array}$ & $\begin{array}{l}\text { Konkurencyjność przedsiębiorstwa to dostosowanie produktów do wymo- } \\
\text { gów rynku i konkurencji, zwłaszcza pod względem asortymentu, jakości, } \\
\text { ceny oraz optymalnych kanałów sprzedaży i metod promocji. }\end{array}$ \\
\hline Aiginger [2006] & $\begin{array}{l}\text { Zdolność kraju lub regionu do tworzenia dobrobytu mierzonego docho- } \\
\text { dem na mieszkańca oraz zestawem wskaźników społecznych i dystry- } \\
\text { bucyjnych oraz wskaźników ekologicznych. Konkurencyjność można } \\
\text { osiagną́ poprzez proces wytwarzania, w którym dochodzi do połaczenia } \\
\text { kapitału fizycznego, nakładów pracy, procesu technicznego, umiejętności } \\
\text { oraz zaufania. }\end{array}$ \\
\hline $\begin{array}{l}\text { Ambastha } \\
\text { i Momaya [2004] }\end{array}$ & $\begin{array}{l}\text { Konkurencyjność przedsiębiorstwa to jego udział w rynku, na którym wy- } \\
\text { stępuje konkurencja. }\end{array}$ \\
\hline $\begin{array}{l}\text { Barker i Köhler } \\
\text { [1997] }\end{array}$ & $\begin{array}{l}\text { Konkurencyjność kraju to zdolność do produkcji dóbr i usług, które wy- } \\
\text { grywaja konkurencje na międzynarodowym rynku, przy jednoczesnym } \\
\text { wzroście realnych dochodów ludności w długim okresie. }\end{array}$ \\
\hline $\begin{array}{l}\text { Buckley, Pass } \\
\text { i Prescott [1988] }\end{array}$ & $\begin{array}{l}\text { Konkurencyjność przedsiębiorstwa to jego zdolność do wytwarzania } \\
\text { i sprzedawania produktów oraz usług o najwyższej jakości i niskich kosz- } \\
\text { tach w porównaniu z konkurentami krajowymi i międzynarodowymi. }\end{array}$ \\
\hline $\begin{array}{l}\text { European } \\
\text { Commission } \\
\text { [2001] }\end{array}$ & $\begin{array}{l}\text { Konkurencyjność narodów to zdolność gospodarek do zapewnienia lud- } \\
\text { ności trwałego i wysokiego standardu życia oraz wysokiej stopy zatrud- } \\
\text { nienia. }\end{array}$ \\
\hline Flejterski [1984] & $\begin{array}{l}\text { Konkurencyjność to zdolność do projektowania i sprzedawania towarów } \\
\text { danej branży, gałęzi lub działu, których ceny, jakość i inne walory są bar- } \\
\text { dziej atrakcyjne od odpowiednich cech towarów oferowanych przez kon- } \\
\text { kurentów. }\end{array}$ \\
\hline Gorynia [2002] & $\begin{array}{l}\text { Konkurencyjność to pojęcie teoretyczne, wielowymiarowe odnoszace się } \\
\text { do rynkowego sposobu regulacji. Konkurencyjność przedsiębiorstwa to } \\
\text { umiejętność osiagania i/lub utrzymania przewagi konkurencyjnej. }\end{array}$ \\
\hline Krugman [1994] & $\begin{array}{l}\text { Konkurencyjność regionów to zdolność do tworzenia dobrobytu (bogac- } \\
\text { twa) i wysokiego poziomu życia ludności. }\end{array}$ \\
\hline
\end{tabular}


cd. tabeli 1

\begin{tabular}{|l|l|}
\hline Autor [rok] & \multicolumn{1}{|c|}{ Definicja } \\
\hline Misala [2008] & $\begin{array}{l}\text { Międzynarodowa konkurencyjność to bieżąca zdolność do osiagania } \\
\text { przez podmioty gospodarcze na terenie danego kraju większych i/lub } \\
\text { porównywalnych korzyści z tytułu uczestnictwa w międzynarodowym po- } \\
\text { dziale pracy z uzyskiwanymi przez podmioty działające w porównywal- } \\
\text { nym otoczeniu gospodarczym. }\end{array}$ \\
\hline Porter [1990] & Konkurencyjność kraju to jego produktywność. \\
\hline $\begin{array}{l}\text { Scott i Lodge } \\
\text { [1985] }\end{array}$ & $\begin{array}{l}\text { Konkurencyjność kraju to zdolność do wytwarzania i dystrybucji produk- } \\
\text { tów w gospodarce międzynarodowej, czego efektem jest wzrost standar- } \\
\text { du życia ludności. }\end{array}$ \\
\hline Świtalski [2005] & $\begin{array}{l}\text { Konkurencyjność pojedynczego przedsiębiorstwa jest zdolnościa do za- } \\
\text { spokajania potrzeb nabywcy w wydajniejszy sposób niż konkurenci. }\end{array}$ \\
\hline $\begin{array}{l}\text { World Economic } \\
\text { Forum [1994] }\end{array}$ & $\begin{array}{l}\text { Konkurencyjność to zdolność kraju lub przedsiębiorstwa do tworzenia } \\
\text { większego bogactwa niż konkurenci na rynku światowym. }\end{array}$ \\
\hline
\end{tabular}

Definicje konkurencyjności uszeregowano alfabetycznie według nazwisk autorów

Źródło: Opracowanie własne na podstawie przeglądu literatury.

Dokonując przeglądu definicji konkurencyjności można zauważyć, że odnoszą się one do krajów, narodów, regionów, sektorów, branż czy przedsiębiorstw. Ogólnie można je określić obiektami (podmiotami) konkurencyjności. Definicje konkurencyjności bardzo często skierowane są na najlepsze podmioty, które są w stanie sprostać konkurencji. Tymczasem na rynku da się wyodrębnić obiekty wysoko, średnio i nisko konkurencyjne, więc wydaje się, że definicja konkurencyjności powinna ten fakt uwzględniać. Należałoby to pojęcie zdefiniować poprzez zbiór cech i właściwości badanego obiektu na tle cech i właściwości innych obiektów działających na rynku.

\section{Koncepcje i teorie konkurencyjności}

Przegląd literatury wskazuje na istnienie wielu koncepcji i teorii ekonomicznych dotyczących zagadnienia konkurencyjności. Jak pokazuje tabela 2, można je podzielić na te, które dotyczą konkurencyjności krajów bądź gospodarek narodowych oraz regionów (skala makro), sektorów bądź branż gospodarki (skala mezo) i odpowiednio przedsiębiorstw (skala mikro). Koncepcje i teorie konkurencyjności w ujęciu ekonomii klasycznej odnoszą się głównie do poziomu makro-, a neoklasycznej - mikroekonomicznego. Są również współczesne podejścia, do których należy przede wszystkim koncepcja konkurencyjności Paula Krugmana i teoria konkurencyjności Michaela Portera. 


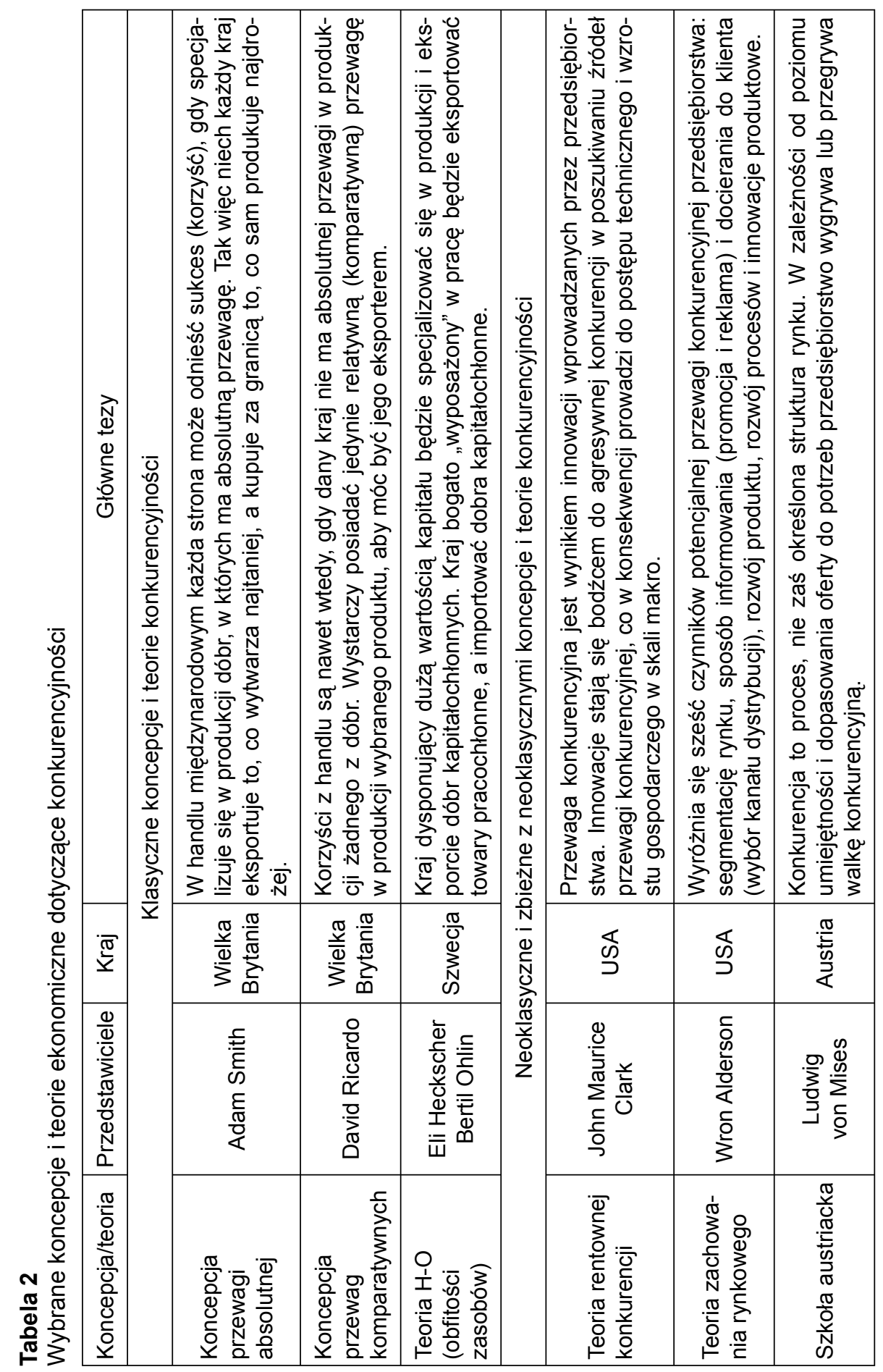




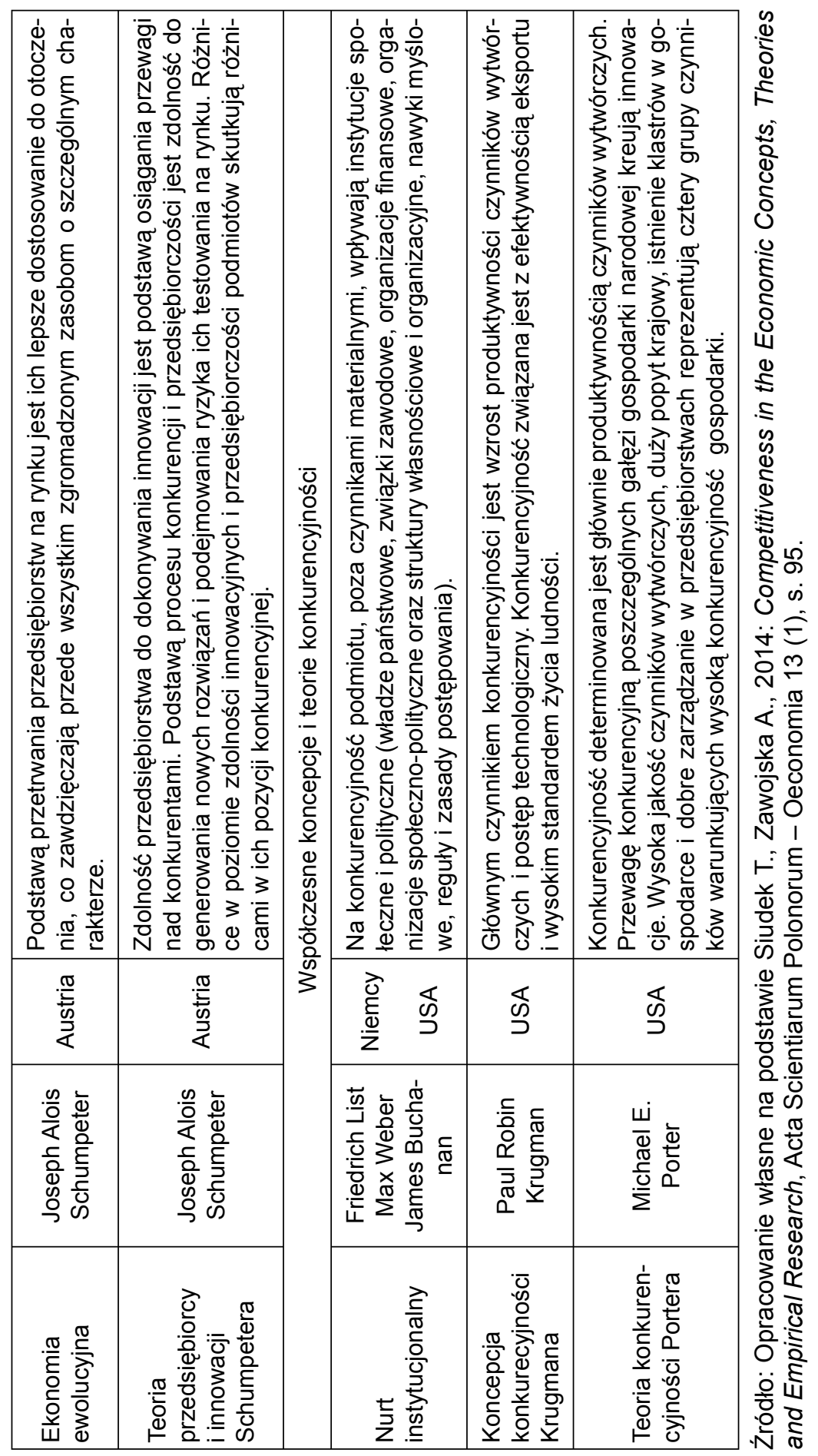


Teorie i koncepcje konkurencyjności w ujęciu makro bardzo często dotyczą handlu międzynarodowego i przewagi komparatywnej krajów wytwarzających określone produkty. Jest również zespół teorii i koncepcji konkurencyjności odnoszące się do rynku, na którym występuje konkurencja doskonała, oligopol czy też monopol.

Są to podejścia klasyczne do konkurencyjności, w których rywalizacja konkurencyjna na rynku jest wyznacznikiem pozycji konkurencyjnej poszczególnych jego uczestników. Są również pojedyncze teorie postulujące interwencję państwa na rynku. Najwięcej teorii i koncepcji konkurencyjności stanowi, że o pozycji konkurencyjnej kraju, regionu bądź przedsiębiorstwa decyduje produktywność czynników wytwórczych.

Szczególnym podejściem do konkurencyjności są teorie przedsiębiorcy i innowacji Josepha Schumpetera, które głoszą, że wyłącznie zdolność do tworzenia innowacji i przedsiębiorczość właściciela decydują o pozycji konkurencyjnej przedsiębiorstwa. Oryginale podejście do konkurencyjności przedstawia teoria gier Johna von Neumana i Oskara Morgensterna, w której z punktu widzenia wszystkich graczy racjonalne na rynku jest zachowanie kooperacyjne, a z punktu widzenia pojedynczego gracza racjonalne jest powstrzymanie się od współpracy.

Podsumowując, koncepcje przewagi absolutnej Adama Smitha oraz przewag komparatywnych Dawida Ricardo wyjaśniają mechanizmy handlu zagranicznego krajów bazujące na ich przewagach w produkcji dóbr. Z kolei teoria przedsiębiorcy i innowacji Schumpetera nacisk kieruje na innowacje jako główne siły sprawcze poprawy konkurencyjności przedsiębiorstw. Wkładem Krugmana do teorii konkurencyjności jest wyjaśnienie, że konkurencyjność w zasadzie nie dotyczy krajów, a przedsiębiorstw, których produktywność jest głównym czynnikiem decydującym o przewadze narodów w handlu zagranicznym i poziomie życia ludności. Z kolei w teorii konkurencyjności Portera na uwagę zasługuje opracowanie czteroczynnikowego modelu konkurencyjności gospodarki zwanego modelem diamentu.

\section{Teoretyczne ujęcie konkurencyjności przedsiębiorstwa}

W literaturze przedmiotu występują trzy ważne podejścia do pomiaru konkurencyjności na poziomie przedsiębiorstwa, mianowicie zaproponowane przez Buckleya i współautorów [1988], Mana i współautorów [2002] oraz Ambastha i Momaya [2004].

Buckley i współautorzy [1988] opracowali model konkurencyjności przedsiębiorstwa składający się z trzech wymiarów: konkurencyjności wynikowej, potencjału konkurencyjnego i procesu konkurencyjnego (rys. 1). Potencjał kon- 
kurencyjny dotyczy nakładów zużywanych w działalności operacyjnej przedsiębiorstwa, a konkurencyjność wynikowa związana jest z jego wynikami z działalności operacyjnej. Proces konkurencyjny z kolei powiązany jest z zarządzaniem przedsiębiorstwem. Według autorów, wymiary podane w modelu obejmują różne wskaźniki konkurencyjności. Wymiar konkurencyjności wynikowej obejmuje wyniki procesów przedsiębiorstw, które można mierzyć za pomocą kilku miar konkurencyjności, jak przykładowo: wzrost eksportu, procentowy udział w rynku czy też poziom rentowności. W ramach potencjału konkurencyjnego Buckley i współautorzy [1988] proponują następujące wskaźniki konkurencyjności: przewaga komparatywna, poziom kosztów, produktywność, wydajność pracy, poziom cen i jakość produktów, dostęp do zasobów (kapitału, wykwalifikowanej siły roboczej i surowców). Według nich wskaźniki potencjału konkurencyjnego nie wyjaśniaja, $\mathrm{w}$ jaki sposób ten potencjał jest transformowany do wymiaru konkurencyjności wynikowej. W modelu są dwa kluczowe elementy potencjału konkurencyjnego przedsiębiorstwa potrzebne do utrzymania konkurencyjności wynikowej: rozwój technologiczny i efektywność działania. Proces zarządzania, będący trzecim wymiarem konkurencyjności, obejmuje wskaźniki ilościowe i jakościowe, np. korzyści z uprawnień własnościowych, zaangażowanie podmiotu $\mathrm{w}$ międzynarodowy biznes, zdolności marketingowe, relacje $\mathrm{w}$ procesie zarządzania czy korzyści skali i zakresu.

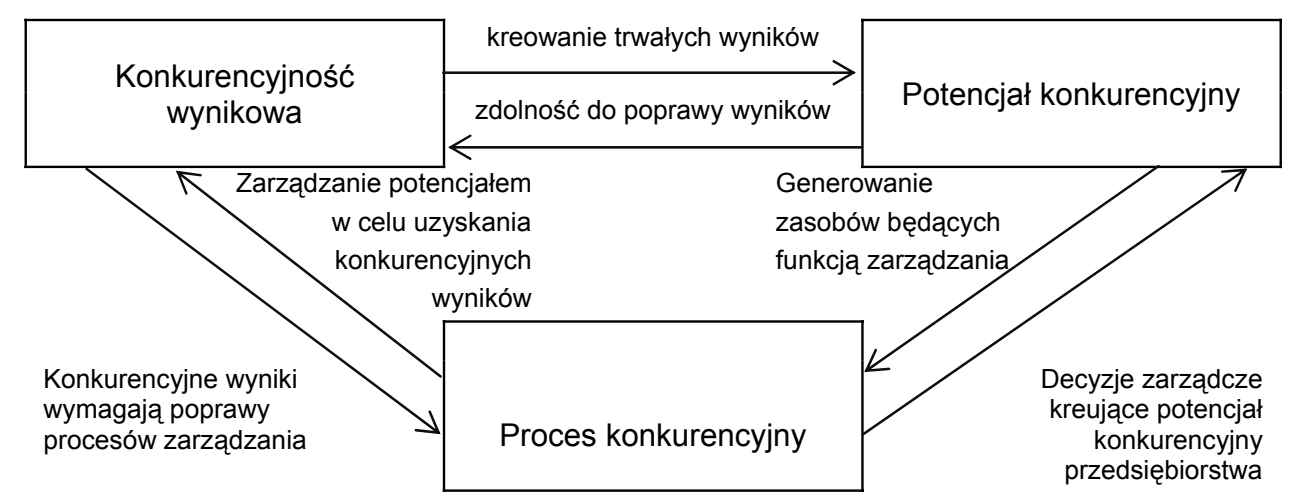

\section{Rysunek 1}

Wzajemne relacje między wymiarami w modelu konkurencyjności przedsiębiorstwa Źródło: Buckley i współautorzy [1988].

Ambastha i Momaya [2004] główny nacisk kładą na elementy konkurencyjności przedsiębiorstwa występujące w aktywach, procesach i wynikach. Ich podejście obejmuje dwa strategiczne poziomy: aktywa i wyniki (pierwszy poziom) oraz proces (drugi poziom). Konkurencyjność na poziomie przedsiębiorstwa 


\section{4}

obejmuje kombinację aktywów i procesów. Aktywa są nieodłącznie związane z zasobami lub infrastruktura, a procesy transformują aktywa w produkty, które sprzedawane na rynku przynoszą przedsiębiorstwu określone korzyści finansowe. Autorzy twierdzą że źródła konkurencyjności (aktywa, procesy i wyniki) zapewniają przewagę konkurencyjną przedsiębiorstwu. W szczególności mogą nimi być: marka, reputacja, kultura organizacyjna, technologia, udział w rynku, produktywność, marketing, rozwój nowych produktów, ceny, koszty, strategia, jakość, innowacje, elastyczność, adaptacyjność, siła perswazji czy też umiejętność projektowania i wdrażania.

W modelu konkurencyjności małych i średnich przedsiębiorstw zaproponowanym przez Mana i współautorów [2002] wzięte są pod uwagę cztery główne składniki: czynniki zewnętrzne, czynniki wewnętrzne, wpływ przedsiębiorcy i wyniki przedsiębiorstwa w długim okresie. Zakłada się, że małe i średnie podmioty różnią się pod względem struktury organizacyjnej, stosunku do środowiska, stylu zarządzania i strategii. Autorzy rozważają głównie wymiary związane z czynnikami wewnętrznymi i sytuacją finansową przedsiębiorstwa. Czynniki wewnętrzne odnoszą się do kapitału i innych zasobów (pracy, technologii itp.) niezbędnych do osiagnnięcia konkurencyjności przedsiębiorstwa. Badacze sugerują że ocenę obu grup przedsiębiorstw w zakresie konkurencyjności należy rozpatrywać z punktu widzenia trzech perspektyw: zdolności przedsiębiorstwa do maksymalizowania zysków, wzrostu przedsiębiorstwa i wyników przedsiębiorstwa względem konkurujących z nim podmiotów.

\section{Mierniki konkurencyjności}

Z praktycznego punktu widzenia ważnym zagadnieniem przy badaniu poziomu konkurencyjności są jej mierniki. Z przeglądu literatury wynika, że w zależności od badaczy preferowane są ich różne rodzaje. Ogólnie można je podzielić na mierniki odnoszące się do skali makro-, mezo- i mikroekonomicznej (tab. 3). W ujęciu makro dotyczą one konkurencyjności krajów i regionów, w ujęciu mezo - branż i sektorów, a w ujęciu mikro pojedynczych przedsiębiorstw.

Mierniki konkurencyjności można również podzielić na jednowymiarowe, dwuwymiarowe i wielowymiarowe. Mierniki jednowymiarowe dotyczą jednej cechy, dwuwymiarowe - dwóch, a wielowymiarowe - wielu cech badanego podmiotu (obiektu). Spotyka się również podział mierników konkurencyjności na mające charakter statyczny i dynamiczny. Pierwsze określają poziom konkurencyjności na dany moment, a drugie informują o zmianach konkurencyjności w czasie. 
Tabela 3

Mierniki konkurencyjności w ujęciu makro-, mezo- i mikroekonomicznym

\begin{tabular}{|c|c|}
\hline Autor/organizacja & Mierniki konkurencyjności \\
\hline \multicolumn{2}{|c|}{ Ujęcie na poziomie makroekonomicznym } \\
\hline Dollar i Wolff [1993] & Produktywność \\
\hline Esty i Porter [2002] & $\begin{array}{l}\text { Produkt krajowy brutto, Produkt narodowy brutto } \\
\text { PKB per capita }\end{array}$ \\
\hline Fagerberg [1988] & Wzrost udziału w rynku \\
\hline Jannsen i Kooths [2012] & Poziom eksportu i jego kierunki \\
\hline Lipschitz i McDonald [1991] & $\begin{array}{l}\text { Realny kurs walutowy } \\
\end{array}$ \\
\hline Markusen [1992] & Realny wzrost dochodów ze zrównoważonym handlem \\
\hline Mulatu i wsp. [2004] & Przepływy handlu międzynarodowego \\
\hline Sharpe [1985] & Udział w rynku \\
\hline Stawska [2014] & $\begin{array}{l}\text { Bezpośrednie inwestycje zagraniczne, kurs walutowy, } \\
\text { stopa inflacji, stopa bezrobocia }\end{array}$ \\
\hline WEF/IMD [1995] & Światowy indeks konkurencyjności \\
\hline \multicolumn{2}{|c|}{ Ujęcie na poziomie mezoekonomicznym } \\
\hline Carbon Trust [2004] & Zysk przed opodatkowaniem \\
\hline Copeland i Taylor [2004] & Eksport \\
\hline Jaffe i Palmer [1997] & Wydatki na badania i rozwój oraz zgłoszone patenty \\
\hline Kordalska i Olczyk [2013] & Eksport netto sektorów przemysłu \\
\hline Lanoie i wsp. [2008] & Produktywność czynników produkcji \\
\hline Leiter i wsp. [2009] & $\begin{array}{c}\text { Przepływy inwestycyjne, bezpośrednie inwestycje } \\
\text { zagraniczne }\end{array}$ \\
\hline Peterson [2003] & Udział w rynku \\
\hline \multicolumn{2}{|c|}{ Ujęcie na poziomie mikroekonomicznym } \\
\hline Balassa [1965] & Korzyści komparatywne \\
\hline Bruno [1965] & Koszt zasobów krajowych \\
\hline Buckley i wsp. [1992] & Wskaźnik wielowymiarowy \\
\hline Durand i Giorno [1987] & Konkurencyjność cenowa \\
\hline Helleiner [1991] & Realny kurs walutowy \\
\hline Hickman [1992] & Jednostkowy koszt pracy \\
\hline Jorgenson i Kuroda [1992] & Konkurencyjność cenowa \\
\hline Krugman i Hatsopoulos [1987] & Udział i zmiany w rynku \\
\hline Porter [1990] & Wskaźnik wielowymiarowy \\
\hline Siggel i Cockburn [1995] & Pełny koszt jednostkowy \\
\hline Swann i Taghavi [1992] & Cena/cechy produktu \\
\hline Turner i Gollub [1997] & Względne jednostkowe koszty pracy \\
\hline Ziętara [2014] & $\begin{array}{c}\text { Dodatni dochód z zarządzania oraz dochód } \\
\text { z gospodarstwa rolnego na poziomie parytetowym }\end{array}$ \\
\hline
\end{tabular}

Źródło: Opracowanie własne na podstawie przeglądu literatury. 
Ponadto wyróżnia się stochastyczne i deterministyczne mierniki konkurencyjności oraz pozytywne i normatywne. Mierniki stochastyczne uwzględniają błędy losowe przy ich szacowaniu, podczas gdy deterministyczne nie biorą ich pod uwagę. Mierniki pozytywne konkurencyjności informują o faktycznym obecnym stanie, podczas gdy normatywne - o tym, jaki powinien on być. Inny podział obejmuje mierniki ex-post i ex-ante. Pierwsze informują o przeszłej lub aktualnej konkurencyjności, a drugie o prognozowanej, mogącej wystapić w przyszłości. Szczegółowy przegląd omawianych mierników przedstawiono w tabeli 3 .

Niezależnie od bogactwa stosowanych mierników konkurencyjności powstaje pytanie o to, które z nich najbardziej odzwierciedlają rzeczywistość. Z racji, że konkurencyjność jest pojęciem wielowymiarowym wydaje się, że najlepiej nadają się do tego mierniki syntetyczne, obejmujące wiele cech. Konkurencyjność przedsiębiorstw powinno porównywać się według poszczególnych branż, ponieważ różnią się one między sobą specyfiką działania. Porównywanie konkurencyjności między krajami i regionami nie musi uwzględniać takich ograniczeń - bardzo często opracowywane są dla nich rankingi niezależnie od miejsca położenia geograficznego, powierzchni, liczby ludności czy zasobów mineralnych. Problemem w badaniach konkurencyjności jest brak porównywalności wyników ze względu na różne cechy wykorzystywane przez badaczy w analizach. Ze względu na dużą zmienność konkurencyjności w miejscu i czasie należy mierniki konkurencyjności stale udoskonalać w celu lepszego odzwierciedlania rzeczywistości.

\section{Determinanty konkurencyjności}

Problematyka konkurencyjności przedsiębiorstw wzbudza duże zainteresowanie nie tylko teoretyków ekonomii i zarządzania, ale też praktyków. Porter [1990] oraz Krugman [1994] twierdza, że to właśnie przedsiębiorstwa, a nie kraje konkurują na rynkach międzynarodowych. Według McGahana [1999], czynniki środowiskowe są mniej więcej jednakowe dla konkurujących przedsiębiorstw, natomiast ich cechy oraz działalność decydują o uzyskiwanych przez nie wynikach finansowych.

W literaturze przedmiotu zaprezentowano wiele badań dotyczących określonych aspektów konkurencyjności przedsiębiorstw, takich jak: marketing [Corbett i Wassenhove 1993], informatyka [Ross i wsp. 1996], jakość produktów [Swann i Tahhavi 1994] czy też potencjał innowacyjny [Grupp i wsp. 1997]. Wskazuja one, że przedsiębiorstwa konkurencyjne muszą być sprawne, opłacalne i utrzymywać wysoki poziom jakości swoich produktów [Hammer i Champy 2006], a elastyczność, sprawność i szybkość działania stają się coraz bardziej istotnymi determinantami ich konkurencyjności [Barney i wsp. 2001]. Z kolei O'Fa- 
rell i Hitchens [1988] przeprowadzili liczne badania nad zależnością wyników przedsiębiorstwa od takich czynników konkurencyjności, jak: cena, jakość, projektowanie, marketing, elastyczność i zarządzanie.

Przegląd literatury wskazuje, że do głównych czynników konkurencyjności przedsiębiorstw należą: aktywa, procesy i wyniki (tab. 4).

Analizując badania empiryczne widać, że brane są często pod uwagę wyłącznie pojedyncze cechy analizowanych podmiotów, co wynika głównie z wy-

\section{Tabela 4}

Determinanty konkurencyjności przedsiębiorstwa - przegląd literatury

\begin{tabular}{|c|c|c|}
\hline \multicolumn{2}{|r|}{ Determinanty konkurencyjności } & Autorzy \\
\hline \multirow{2}{*}{$\sum_{\substack{\frac{\pi}{<} \\
\frac{\pi}{\pi}}}^{\pi}$} & $\begin{array}{l}\text { Zasoby ludzkie, struktura przedsiębior- } \\
\text { stwa, kultura firmy }\end{array}$ & Horne i wsp. [1992] \\
\hline & $\begin{array}{l}\text { Technologie } \\
\text { Zaufanie }\end{array}$ & $\begin{array}{c}\text { Khalil [2000]; Mehra [1998] } \\
\text { Barney i wsp. [2001] }\end{array}$ \\
\hline \multirow{5}{*}{ 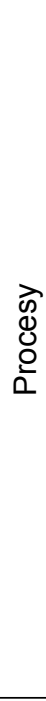 } & $\begin{array}{l}\text { Procesy zarzadzania strategicznego: } \\
\text { - kompetencje } \\
\text { - strategia konkurencyjna } \\
\text { - elastyczność i zdolność adaptacyjna }\end{array}$ & $\begin{array}{c}\text { Sushil i Kak [1997] } \\
\text { Sushil i Kak [1997] } \\
\text { Porter [1990]; Grupp [1997] } \\
\text { O'Farell [1988] }\end{array}$ \\
\hline & $\begin{array}{l}\text { Procesy w ramach zasobów ludzkich } \\
\text { - planowanie i wyszukiwanie talentów }\end{array}$ & Smith [1995] \\
\hline & $\begin{array}{l}\text { Procesy technologiczne: } \\
\text { - innowacje } \\
\text { - systemy } \\
\text { - IT } \\
\end{array}$ & $\begin{array}{c}\text { Khalil [2000] } \\
\text { Grupp [1997] } \\
\text { Ross i wsp. [1996] }\end{array}$ \\
\hline & $\begin{array}{l}\text { Procesy operacyjne: } \\
\text { - produkcja } \\
\text { - projektowanie } \\
\text { - jakość } \\
\end{array}$ & $\begin{array}{c}\text { Kanter [1993] } \\
\text { O'Farell i Hitchens [1988] } \\
\text { Dou i Philip [1998] }\end{array}$ \\
\hline & $\begin{array}{l}\text { Procesy marketingowe: } \\
\text { - marketing } \\
\text { - zarządzanie relacjami } \\
\text { - siła przekonywania } \\
\end{array}$ & $\begin{array}{c}\text { Corbett i Wassenhove [1993] } \\
\text { Hammer i Champy [1993]; Porter [2001] } \\
\text { Feurer i Chaharbaghi [1994] }\end{array}$ \\
\hline 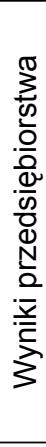 & $\begin{array}{l}\text { Produktywność } \\
\text { Finanse } \\
\text { Udziały w rynku } \\
\text { Zróżnicowanie } \\
\text { Rentowność } \\
\text { Cena } \\
\text { Koszty } \\
\text { Asortyment produktów } \\
\text { Efektywność } \\
\text { Tworzenie wartości } \\
\text { Satysfakcja klienta } \\
\text { Rozwój nowych produktów } \\
\end{array}$ & $\begin{array}{c}\text { McKee i Sessions-Robinson [1989] } \\
\text { Francis [1989] } \\
\text { Mehra [1998] } \\
\text { Buckley i wsp. [1988] } \\
\text { Schwalbach [1989] } \\
\text { Porter [1990] } \\
\text { Pace i Stephan [1996]; Scott i Lodge [1985] } \\
\text { Dou i Philip [1998] } \\
\text { Porter [1990] } \\
\text { Dou i Philip [1998] } \\
\text { Porter [1990] } \\
\text { Hammer i Champy [1993]; Man i wsp. [2002] }\end{array}$ \\
\hline
\end{tabular}

Źródło: Ambastha i Momaya [2004]. 


\section{8}

gody badaczy, ponieważ mogą je łatwo porównywać. Najtrudniejsze w badaniu konkurencyjności jest porównywanie krajów, regionów, sektorów, branż i przedsiębiorstw, przy którym uwzględnia się wiele cech. Wtedy największym problemem jest ich wybór oraz ustalenie dla nich wag według ich ważności.

\section{Podsumowanie}

1. Konkurencyjność podmiotów (krajów, regionów, sektorów, branż czy przedsiębiorstw) determinują: państwo, rynek oraz ich własny potencjał. Państwo poprzez regulacje określa zasady i reguły konkurowania. Rynek, a zwłaszcza jego struktura, decyduje o sile konkurencji. Potencjał (aktywa i procesy) podmiotu stanowi wyznacznik jego pozycji konkurencyjnej.

2. Przegląd koncepcji i teorii ekonomicznych oraz badań empirycznych na świecie wskazuje, że za główne czynniki konkurencyjności przedsiębiorstw można uznać: rozwój technologiczny i potencjał innowacyjny, udział w rynku, produktywność czynników wytwórczych i koszty produkcji, poziom cen i jakość produktów, przedsiębiorczość, elastyczność i sprawność działania, adaptacyjność, strategia oraz instytucje społeczne i polityczne.

3. Konkurencyjność przedstawiana jest w ujęciu popytowym lub zasobowym. Pierwszą określa się na podstawie zdolności pozyskiwania przez badane podmioty akceptacji rynkowej (np. satysfakcji konsumentów), a drugą na podstawie zasobów i procesów występujących w tych podmiotach.

4. Zakres badań konkurencyjności jest bardzo rozległy. Można ją rozpatrywać w skali makro-, mezo- i mikroekonomicznej. W badaniach na poziomie makro i mezo wykorzystuje się z reguły dane statystyki masowej, a na poziomie mikro - dane pierwotne. Wpływ na wyniki ma wiarygodność danych, szczególnie istotna na poziomie makro i mezo, ponieważ urzędy statystyczne albo nie uwzględniają, albo jedynie szacują szarą strefę gospodarki.

5. Przy mierzeniu poziomu konkurencyjności powinno stosować się wskaźniki wielowymiarowe, ponieważ pojęcie konkurencyjności obejmuje wiele aspektów i obszarów działania krajów, sektorów, branż i przedsiębiorstw. Problematyczny jest dobór cech (zmiennych) wykorzystywanych do konstruowania wskaźników syntetycznych oraz ustalenie dla nich wag odzwierciedlających stopień ich ważności.

6. Przydatność badań konkurencyjności krajów, regionów, sektorów czy branż gospodarki jest dostrzegalna. Przykładowo, dostarczona przez nie informacja o pozycji konkurencyjnej określonych obiektów może być wykorzystana przez władze szczebla centralnego i samorządowego w procesie tworzenia polityki gospodarczej. 


\section{Literatura}

ADAMKIEWICZ-DRWIŁŁO H.G., 2002: Uwarunkowania konkurencyjności przedsiębiorstw, Wydawnictwo Naukowe PWN, Warszawa.

AIGINGER K., 2006: Competitiveness: From a Dangerous Obsession to a Welfare Creating Ability with Positive Externalities, Journal of Industry, Competition and Trade 6(2), 161-177 .

AMBASTHA A., MOMAYA K., 2004: Competitiveness of Firms: Review of Theory, Frameworks, and Models, Singapore Management Review 26(1), 45-61.

BALASSA B., 1965: Trade Liberalization and "Revealed" Comparative Advantage, The Manchester School 33(2), 99-123.

BARKER T., KÖHLER J., 1997: Competitiveness and Environmental Policy, Environmental Institute, University College, Dublin.

BARNEY J., WRIGHT M., KETCHEN D.J., 2001: The Resource-based View of the Firm: Ten Years after 1991, Journal of Management 27(6), 625-641.

BRUNO M., 1965: The Optimal Selection of Export-promoting and Import-substituting Projects, [w:] Planning the External Sector: Techniques, Problems and Policies, United Nations, New York.

BUCKLEY P.J., PASS C.L., PRESCOTT K., 1988: Measures of International Competitiveness: A Critical Survey, Journal of Marketing Management 4(2), 175-200.

BUCKLEY P.J., 1992: The Meaning of Competitiveness, [w:] Servicing International Markets: Competitive Strategy of Firms, Blackwell, Oxford, 12-39.

Carbon Trust, 2004: The European Emissions Trading Scheme: Implications for Industrial Competitiveness, Available from: http://www thecarbontrust.co.uk/carbontrust/ (data dostępu:12.10.2014).

COPELAND B.R., TAYLOR M.S., 2004: Trade, growth and the environment, Journal of Economic Literature 42(1), 7-71.

CORBETT C., WASSENHOVE L., 1983: Trade offs? What Trade-offs? Competence and Competitiveness in Manufacturing, California Management Review 35(4), 107-122.

DOLlAR D., WOLFF E.N., 1993: Competitiveness, Convergence and International Specialization, The MIT Press, Cambridge.

DOU W., PHILIP H., 1998: The Competitiveness of EU Insurance Industries, The Services Industries Journal 18(1), 39-54.

DURAND M., GIORNO C., 1987: Indicators of International Competitiveness: Conceptual Aspects and Evaluation, OECD Journal Economic Studies 9, 147-182.

ESTY D.C., PORTER M.E., 2002: Ranking National Environmental Regulation and Performance: A Leading Indicator of Future Competitiveness? [w:] M.E. Porter, J.D. Sachs, P.K. Cornelius, J.W. McAuthur, K. Schwab (eds.), The Global Competitiveness Report 2001-2002, Oxford University Press, Oxford, 78-101.

European Commission, 2001: The Competitiveness of European Manufacturing, Brussels.

FAGERBERG J., 1988: International Competitiveness, The Economic Journal 98(391), 355-374.

FEURER R., CHAHARBAGHI K., 1994: Defining Competitiveness: A Holistic Approach, Management Decision 32(2), 49-58. 
FLEJTERSKI S., 1984: Istota i mierzenie konkurencyjności międzynarodowej, Gospodarka Planowa: Miesięcznik poświęcony problemom planowania i rozwoju gospodarki narodowej 39(9), 390-394.

FRANCIS A., 1989: The Competitiveness of European Industry, Routledge, New York.

GORYNIA M. (red.), 2002: Luka konkurencyjna na poziomie przedsiębiorstwa a przystapienie Polski do Unii Europejskiej, Wydawnictwo AE, Poznań.

GRUPP H., 1997: The Links between Competitiveness, Firm Innovative Activities and Public R\&D Support in Germany: An Empirical Analysis, Technology Analysis Strategy 9(1), $19-33$.

HAMMER M., CHAMPY J., 2006: Reengineering the Corporation: A Manifesto for Business Revolution, Harper Business, New York.

HELLEINER G.K., 1991: Increasing International Competitiveness: A Conceptual Framework, [w:] Y. Wen J. Sengupta (eds.), Increasing the International Competitiveness of Exports from Caribean Countries, Economic Development Institute, World Bank, Washington.

HICKMAN B.G., 1992: International Productivity and Competitiveness: An Overview, [w:] Hickman (ed.), International Productivity and Competitiveness, Oxford University Press, New York.

HORNE M., LLOYD P., PAY J., ROE P., 1992: Understanding the Competitive Process: A Guide to Effective Intervention in Small Firms Sector, European Journal of Operational Research 56(1), 54-66.

JAFFE A.B., PALMER K., 1997: Environmental Regulation and Innovation: A Panel Data Study, The Review of Economics and Statistics 79(4), 610-619.

JANNSEN N., KOOTHS S., 2012: German Trade Performance in Times of Slumping Euro Area Markets, Economic Trends 47(6), 368-372.

JORGENSON D.W., KURODA M., 1992: Productivity and International Competitiveness in Japan and the United States 1960-1985, [w:] Ch. Hickman (ed.), International Productivity and Competitiveness, Oxford University Press, New York.

KAK A., 2003: Global Competitiveness with Core Competence: A study of HCL, Paradigm 7, 82-92.

KANTER R.M., 1993: Country Competitiveness, Oxford University Press, New York.

KHALIL T.M., 2000: Management of Technology: The Key to Competitiveness and Wealth Creation, McGraw Hill, Boston.

KRUGMAN P., 1994: Competitiveness: A Dangerous Obsession, Foreign Affairs 73(2), $28-44$.

KORDALSKA A., OLCZYK M., 2013: Konkurencyjność sektorów przemystu przetwórczego i ich wplyw na międzynarodowa konkurencyjność gospodarki polskiej-analiza panelowa, IX Kongres Ekonomistów Polskich, PTE, Warszawa.

KRUGMAN P., HATSOPOULOS G.N., 1987: The Problem of U.S. Competitiveness in Manufacturing, New-England Economic Review, January/February, 18-29.

LANOIE P., LAURENT-LUCCHETTI J., JOHNSTONE N., AMBEC S., 2007: Environmental Policy, Innovation and Performance: New Insights on the Porter Hypothesis, Working Paper No. 2007-07, Grenoble Applied Economics Laboratory (GAEL).

LECH A., 2001: Definicje i miary międzynarodowej konkurencyjności gospodarki, Gospodarka w Teorii i Praktyce 2(9), 77-86. 
LEITER A.M., PAROLINI A., WINNER H., 2009: Environmental Regulation and Investment: Evidence from European Industries, Working Papers 2009-04, Faculty of Economics and Statistics, University of Innsbruck.

LIPSCHITZ L., McDONALD D., 1991: Real Exchange Rates and Competitiveness: A Clarification of Concepts and Some Measurements for Europe, IMF Working Paper, March.

MAN W.Y., LAU T., CHAN K.F., 2002: The Competitiveness of Small and Medium Enterprises. A Conceptualization with Focus on Entrepreneurial Competencies, Journal of Business Venturing 17(2), 123-142.

MARKUSEN J.R., 1992: Productivity, Competitiveness, Trade Performance and Real Income: The Nexus Among Four Concepts, Economic Council of Canada, Ottawa.

McGAHAN A.M., 1999: Competition, Strategy and Business Performance, California Management Review 41(3), 74-101.

McKEE K., SESSIONS-ROBINSON C., 1989: Manufacturing Productivity and Competitiveness, Journal of Manufacturing 3, 35-39.

MEHRA S., 1998: Perpetual Analysis and Continuous Improvement: A Must for Organizational Competitiveness, Managerial Finance 24(1), 19-27.

MISALA J., 2008: Międzynarodowa konkurencyjność gospodarki narodowej; wybrane aspekty teoretyczne, [w:] W. Bieńkowski, Z. Czajkowki, M. Gomułka, B. Brocka-Palacz, E. Latoszek, J. Misala, M. Weresa, Czynniki i miary międzynarodowej konkurencyjności gospodarek w kontekście globalizacji - wstępne wyniki badań, Prace i Materiały Instytutu Gospodarki Światowej SGH 284, 51-71.

MULATU A., FLORAX R., WITHAGEN C., 2004: Environmental Regulation and International Trade, Tinbergen Institute Discussion Paper, 04-020/3, Tinbergen Institute.

O'FARELL P., HITCHENS D.W., 1988: The Relative Competitiveness and Performance of Small Manufacturing Firms in Scotland and the Mid-West of Ireland: An Analysis of Matched Pairs, Regional Studies 25(5), 399-416.

PACE R.W., STEPHAN E.G., 1996: Paradigms of Competitiveness, Journal of Global Competitiveness $6(1), 8-13$.

PETERSON S., 2003: The EU Emission Trading Scheme and its Competitiveness Effects for European Business: Results from the CGE Model DART, Kiel Institute for World Economics.

PORTER M.E., 1990: The Competitive Advantage of Nations. The Free Press, New York.

PORTER M.E., 2001: The Success Formula, Chartered Financial Analyst, February, 37.

ROSS J.W., BEATH C.M., GOODHUE D.L., 1996: Developing Long-term Competitiveness through IT Assets, Sloan Management Review 38(1), 31-42.

SCHWALBACH J., 1989: Profitability and Market Share: A Relationship Reflection on the Functional Relationship, Strategic Management Journal 12(4), 299-306.

SCOTT B.R., LODGE G.C. (eds.), 1985: U.S. Competitiveness in the World Economy, Harvard Business School Press, Boston.

SHARPE A., 1985: Can Canada Compete? Part 1: Measuring Canada's Competitiveness, Canada's Position in the World, Canadian Business Review 12(14), 34-37.

SIGGEL E., COCKBURN J., 1995: International Competitiveness and its Sources: A Method of Development Policy Analysis, Concordia University Department of Economics, Discussion Paper 9517. 
SIUDEK T., ZAWOJSKA A., 2014: Competitiveness in the Economic Concepts, Theories and Empirical Research, Acta Scientiarum Polonorum - Oeconomia 13(1), 91-108.

SMITH S., 1995: World Class Competitiveness, Managing Service Quality 5(5), 36-42.

STAWSKA J., 2014: Konkurencyjność polskiej gospodarki w kontekście ostatniego kryzysu finansowego, Przedsiębiorczość i Zarządzanie 15(10), 373-388.

SWANN P., TAGHAVI M., 1992: Measuring Price and Quality Competitiveness: A Study of Eighteen British Product Markets, Avebury, Aldershot, Hampshire, England.

ŚWITALSKI W., 2005: Innowacyjność i konkurencyjność, Wyd. Uniwersytetu Warszawskiego, Warszawa.

TURNER A.G., GOLUB S.S., 1997: Towards a System of Unit Labor Cost-Based Competitiveness Indicators for Advanced, Developing, and Transition Countries, IMF Working Paper 97/151.

WEF/IMD 1995: The World Competitiveness Report, World Economic Forum and Institute for Management Development, Geneva and Lausanne.

World Economic Forum, 1994: The World Competitiveness Report 1994, Lausanne.

WZIATĘK-KUBIAK A., 2003: Konkurencyjność polskiego przemystu, Wyd. Bellona, Warszawa.

ZIĘTARA W., 2014: Pozycja konkurencyjna polskich gospodarstw rolnych na tle gospodarstw wybranych krajów europejskich, Problemy Drobnych Gospodarstw Rolnych 4, 63-78.

\section{Abstrakt}

Celem opracowania jest przedstawienie aktualnej wiedzy na temat konkurencyjności krajów i regionów, a także sektorów i pojedynczych przedsiębiorstw w gospodarce narodowej z punktu widzenia koncepcji konkurencyjności, jej pomiaru i determinant. W tym artykule krytycznie analizuje się zarówno literaturę teoretyczną, jak i empiryczną z zakresu konkurencyjności, można dowiedzieć się, że konkurencyjność jest bardzo złożonym, wieloaspektowym zjawiskiem lub procesem i ma wiele zastosowań w różnych (makro, mezo i mikro) domenach. W empirycznych badaniach stosuje się różne mierniki i determinanty konkurencyjności, co sprawia, że wyniki nie są porównywalne między krajami, regionami, sektorami i przedsiębiorstwami.

Słowa kluczowe: konkurencyjność, teorie, koncepcje, mierniki, determinanty

\section{Theoretical and applied aspects of the competitiveness - a review of the literature}

The purpose of this study is to set out what is currently known about the competitiveness of the countries and regions as well as of sectors and individual enterprises in the national economy from the point of view of understanding 
the concept of competitiveness, its measurement and determinants. This paper critically examines both theoretical and empirical literature on the competitiveness, finding out that competitiveness is a very complex, multifaceted phenomenon or process and has many uses in different (macro, meso and micro) domains. The empirical studies on competitiveness apply a variety of competitiveness measures and determinants making it sometimes difficult to compare their results across countries, regions, sectors and enterprises.

Key words: competitiveness, theories, concepts, measures, determinants 
